\title{
Mechanical Properties of Glass Fiber Reinforced Concrete
}

\author{
Muna M .Abdullah Eman K.Jallo \\ Dept.civil engineering Dept.civil engineering
}

\begin{abstract}
:
This paper described an experimental study of some mechanical properties of glass fibers reinforced mortar (GFRM) and concrete (GFRC), namely tensile, compressive strength and young 's modulus. The investigation is designed to find out the effect of glass fiber content $(0,600,1000$, and 1400$) \mathrm{gm} / \mathrm{m}^{3}$ on the mechanical properties of glass fiber reinforced concrete and mortar at 28 and 14 days respectively. The results indicate that the addition $(600,1000,1400) \mathrm{gm} / \mathrm{m}^{3}$ of glass fiber to concrete and mortar increased the splitting tensile strength by approximately $(1,4.3,12.5) \%$ and $(5.4,7.7,17) \%$ for concrete and mortar respectively. The results indicate also that compressive strength of concrete increased by ratios (3.6,7.1,9.3)\% and for the mortar increases by (2) \% for fibers content $(600) \mathrm{gm} / \mathrm{m}^{3}$ and $(0.8,0.4) \%$ for fibers content $(1000,1400) \mathrm{gm} / \mathrm{m}^{3}$. Based on this study the young modulus of GFRC increased by $(9.7,56.6,84) \%$ due to glass fibers content in concrete.
\end{abstract}

Key words: glass fiber, concrete, mortar, compressive strength, tensile strength.

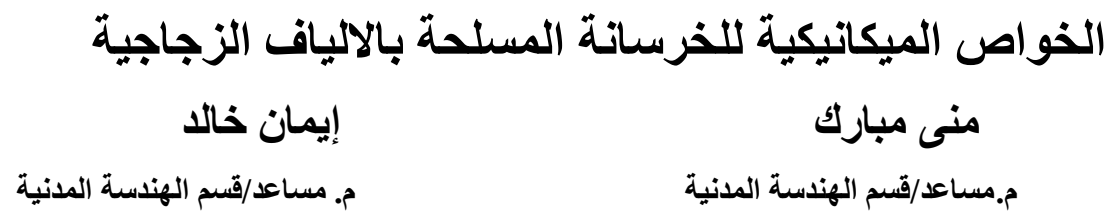

\section{الخلاصة}

تضمن البحث دراسة عملية لبعض الخواص الميكانيكية المتمثلة بمقاومة الانضغاط والثدافة ومعامل يونج لكل من

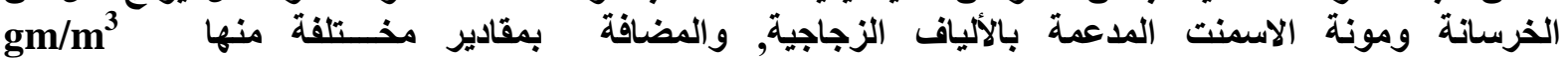

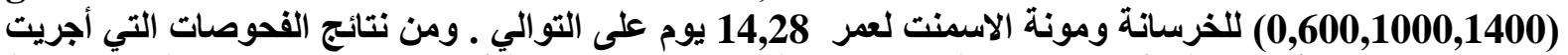

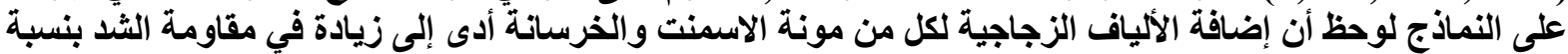

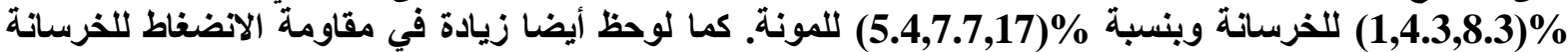

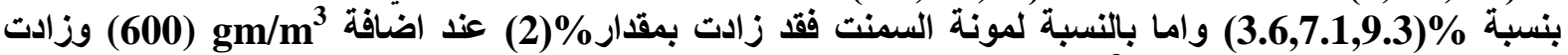

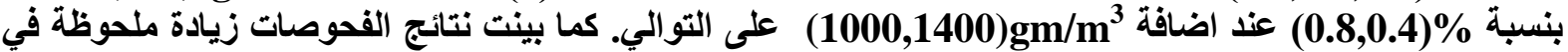
معامل المرونة للخرسانة بنسبة \%) (9.7,56.6, 84) لنفس مقادير الأليافت المستخدمة. 


\section{Introduction:}

Glass Fiber Reinforced Concrete (GFRC) is a type of fiber reinforced concrete, mainly used in exterior building facade panels and as architectural precast concrete. This material is very good in making fair face in front of any building and it is less dense than steel. Glass fiber reinforced composite materials consist of high strength glass fiber embedded in a cementitious matrix. In this form, both fibers and matrix retain their physical and chemical identities, yet they produce a combination of properties that cannot be achieved with either of the components acting alone. In general fibers are the principal load-carrying members, while the surrounding matrix keeps them in the desired locations and orientation, acting as a load transfer medium between them, and protects them from environmental damage. In fact, the fibers provide reinforcement for the matrix and other useful functions in fiber-reinforced composite materials. Glass fibers can be incorporated into a matrix either in continuous lengths or in discontinuous (chopped) lengths.

The potential for using a glass fiber reinforced concrete system was recognized by Russians in the 1940s. The early work on glass fiber reinforced concrete went through major modifications over the next few decades. Early conventional borosilicate glass caused reduction in strength due to alkali reactivity with the cement paste. Alkali resistant glass fibers (AR glass) were then produced resulting in long term durability, but other strength loss trends were observed. Better durability result was observed when AR glass is used with developed low alkaline cement.

There are number differences between structural metal and fiber-reinforced composites. For example, metals in general exhibit yielding and plastic deformation whereas most fiberreinforced composites are elastic in their tensile stress-strain characteristics. However, the dissimilar nature of these materials provides mechanisms for high-energy absorption on a microscopic scale comparable to the yielding process. Depending on the type and severity of external loads, a composite laminate may exhibit gradual deterioration in properties but usually would not fail in catastrophic manner. Mechanisms of damage development and growth in metal and composite structure are also quite different. Other important characteristics of many fiber-reinforced composites are their non-corroding behavior, high damping capacity and low coefficients of thermal expansion. [1]

Many experiments on fiber reinforced concrete with steel fibers and synthetic fibers have been conducted to obtain fundamental properties of mortar and concrete reinforced with glass fibers, such as tensile and compressive properties. Effect of fiber content on these properties was examined and some problems were theoretically discussed.

Junji Takagi [2] investigated the effect of the length of randomly distributed fibers and the glass content on the flexural strength, compressive strength, tensile strength and young, s modulus of the materials. The author found that an increased in strength as the glass content increased, the fiber inclusion up to $1 \%$ by weight in the mortar and concrete hardly influenced young, s modulus both in compression and tension.

Yuan [3] investigated the relation between the splitting tensile strength and compressive strength of glass fibers reinforced concrete (GFRC) and polypropylene fiber reinforced concrete (PFRC). The fiber content was $1 \%$ and $1.5 \%$ of the mixed concrete by volume. A total of 18 cylinder specimens were made from each mix for compressive and splitting tensile tests. The authors found that the addition of GF and PF. To concrete increased the splitting tensile strength by approximately $20-50 \%$, and the splitting tensile strength of GFRC and PFRC ranged from $9 \%$ to $13 \%$ of its compressive strength.

P.S.Song et.al. [4]. Investigated the strength potential of nylon fiber reinforced concrete versus that of the polypropylene fiber reinforced concrete, at fiber content of $600 \mathrm{gm} / \mathrm{m}^{3}$. 
The authors found that, the compressive and splitting tensile strength and modulus of rupture of the nylon fiber concrete improved by $6.3 \%, 6.7 \%$ and $4.3 \%$ respectively, over those of polypropylene fiber concrete. The shrinkage crack reducing potential of the nylon fiber in mortar went moderatately ahead of that of the polypropylene fibers.

This investigation was planned to obtain fundamental properties of mortar and concrete reinforced with glass fibers. Effect of glass fiber content on these properties was examined and some problems were theoretically discussed.

\section{Experimental program:}

Materials:

Materials used in this research for ordinary concrete were as follow:

1. Cement: the used cement was obtained from Badosh cement factory in Ninavha Governorate. The physical properties for this type of cement showed in table (1) according to IQS: 5/1984 [5]. And the chemical properties for the cement are showen in table (2) according to the ASTM specification C150 [6].

2. Water: tap water (potable) was used for mixing and curing purpose.

3. Fine aggregate: river sand was used according to the (BS882:1983) [7]. Sand sieve analysis is shown in table (3).

4. Coarse aggregate: river aggregate with M.A.S. (10) $\mathrm{mm}$ was used. Its sieve analysis shown in table (4).

5. Glass fiber: use different mix content $\left(0,600,1000\right.$, and 1400) gm/ $/ \mathrm{m}^{3}$. Some glass fiber properties are shown in table (5):

Table 1, physical properties of OPC cement.

\begin{tabular}{|c|c|c|}
\hline Test & Result & IQS:5/1984 \\
\hline Consistency & 0.29 & $0.24-0.32$ \\
\hline Initial setting time (min.) & 210 & min. 45 min. \\
\hline Final setting time (min.) & 330 & Max 600 min. \\
\hline Fineness (\%) & 5 & Max. 10\% \\
\hline
\end{tabular}

Table 2, chemical properties of OPC cement

\begin{tabular}{|c|c|c|c|c|c|}
\hline $\begin{array}{c}\text { Chemical } \\
\text { Composition }\end{array}$ & $\begin{array}{c}\text { Value } \\
\text { \% }\end{array}$ & $\begin{array}{c}\text { Limits \% } \\
\text { ASTM :C150 }\end{array}$ & $\begin{array}{c}\text { Chemical } \\
\text { Composition }\end{array}$ & $\begin{array}{c}\text { Value } \\
\text { \% }\end{array}$ & $\begin{array}{c}\text { Limits \% } \\
\text { ASTM :C150 }\end{array}$ \\
\hline $\mathrm{SiO}_{2}$ & 21.7 & ---- & $\mathrm{R}_{2} \mathrm{O}_{3}$ & 7.35 & ---- \\
\hline $\mathrm{AL}_{2} \mathrm{O}_{3}$ & 4.67 & ---- & $\mathrm{HM}$ & 1.84 & ---- \\
\hline $\mathrm{Fe}_{2} \mathrm{O}_{3}$ & 2.68 & ---- & $\mathrm{SIM}$ & 2.95 & ---- \\
\hline $\mathrm{CaO}$ & 53.35 & ---- & AM & 1.74 & ---- \\
\hline $\mathrm{MgO}$ & 3.4 & 6 & L.S.F & 77.31 & ---- \\
\hline $\mathrm{SO}_{3}$ & 1 & 3 & Free Lime & 1.1 & ---- \\
\hline $\mathrm{C}_{3} \mathrm{~S}$ & 14.21 & ---- & Loss on ignition & 2 & 3 \\
\hline $\mathrm{C}_{2} \mathrm{~S}$ & 51.49 & ---- & Insoluble residue & 0.4 & 0.75 \\
\hline $\mathrm{C}_{3} \mathrm{~A}$ & 7.84 & ---- & & & \\
\hline $\mathrm{C}_{4} \mathrm{AF}$ & 8.16 & ---- & & & \\
\hline Solid Solution & 14.37 & ---- & & & \\
\hline $\mathrm{C}_{2} \mathrm{~F}$ & 6.21 & ---- & & & \\
\hline
\end{tabular}


Table 3, Sand sieve analysis

\begin{tabular}{|r|c|c|c|c|c|}
\hline $\begin{array}{r}\text { SEIVES } \\
(\mathbf{m m})\end{array}$ & $\begin{array}{c}\text { PASSING } \\
\text { \% }\end{array}$ & $\begin{array}{c}\text { SPESIFICATION } \\
\text { LIMIT (BS882-1983) }\end{array}$ & $\begin{array}{c}\text { Lower } \\
\text { limit }\end{array}$ & $\begin{array}{c}\text { Medium } \\
\text { limit }\end{array}$ & $\begin{array}{c}\text { Upper } \\
\text { limit }\end{array}$ \\
\hline $\begin{array}{r}5 \mathrm{~mm} \\
(\mathrm{No} .4)\end{array}$ & 100 & $89-100$ & ---- & ------ & ---- \\
\hline $\begin{array}{r}2.36 \mathrm{~mm} \\
(\text { No.8})\end{array}$ & 86 & $60-100$ & $60-100$ & $65-100$ & $80-100$ \\
\hline $\begin{array}{r}1.18 \mathrm{~mm} \\
(\mathrm{No.16})\end{array}$ & 70 & $30-100$ & $30-100$ & $45-100$ & $70-100$ \\
\hline $\begin{array}{r}0.6 \mathrm{~mm} \\
(\mathrm{No.30})\end{array}$ & 49 & $15-100$ & $15-54$ & $25-80$ & $55-100$ \\
\hline $\begin{array}{r}0.3 \mathrm{~mm} \\
(\mathrm{No.50})\end{array}$ & 17 & $5-70$ & $5-40$ & $5-48$ & $5-70$ \\
\hline $\begin{array}{r}0.15 \mathrm{~mm} \\
(\mathrm{No.10})\end{array}$ & 4 & $0-15$ & ------ & ------ & ------ \\
\hline
\end{tabular}

Table 4, Aggregate sieves analysis

\begin{tabular}{|c|c|c|}
\hline SEIVES (mm) & Cumulative \% & $\begin{array}{c}\text { SPESIFICATIN LIMIT } \\
\text { ( BS882-1983) }\end{array}$ \\
\hline $14 \mathrm{~mm}(1 / 2 \mathrm{in})$ & 100 & 100 \\
\hline $10 \mathrm{~mm}(3 / 8 \mathrm{in})$ & 89 & $85-100$ \\
\hline $5 \mathrm{~mm}($ No.4) & 22 & $0-25$ \\
\hline $2.36 \mathrm{~mm}$ (No.8) & 0 & $0-5$ \\
\hline
\end{tabular}

Table 5, Properties of glass fiber

\begin{tabular}{|c|c|c|c|c|}
\hline $\begin{array}{c}\text { Cross } \\
\text { section }\end{array}$ & Fiber length & Tensile strength & $\begin{array}{c}\text { Young } \\
\text { modules }\end{array}$ & Specific density \\
\hline rectangular & $6 \mathrm{~mm}$ & $400 \mathrm{~N} / \mathrm{mm}^{2}$ & $2.600 \mathrm{~N} / \mathrm{mm}^{2}$ & $0.91 \mathrm{gm} / \mathrm{cm}^{3}$ \\
\hline
\end{tabular}

\section{Mixing and curing:}

During the investigation, both mortar and concrete specimens were tested. The mortar mix consisted of 1 part cement to two parts sand and 0.5 water by weight. The concrete mix $(1: 2: 4: 0.5)$ by weight.The procedures for mixing the fiber-reinforced concrete involved the following:- Firstly, the gravel and sand and cement were placed in a concrete mixer and dry mixed for $2 \mathrm{~min}$. Secondly, the specified amount of fibers was distributed and mixed for 1 min. After which, the mixing water was slowly added and mixed for $2 \mathrm{~min}$. Lastly, the freshly mixed fiber-reinforced concrete was cast, placed into the cylinder molds for the splitting tensile strength specimens measuring 150*300 mm, and into $100 * 100 \mathrm{~mm}$ cubic molds for the compressive specimens. The casting and finishing of specimens were made in a laboratory at a temperature of $23{ }^{\circ} \mathrm{C}$. The specimens were in the molds approximately $24 \mathrm{~h}$, and then cured in water at $23^{\circ} \mathrm{C}$ for 28 days for concrete, and 14 days for mortar, and then removed and kept at room temperature until the time of testing. Fig. (1) Show the machine used in the testing specimens of concrete and mortar reinforced with glass fiber. 

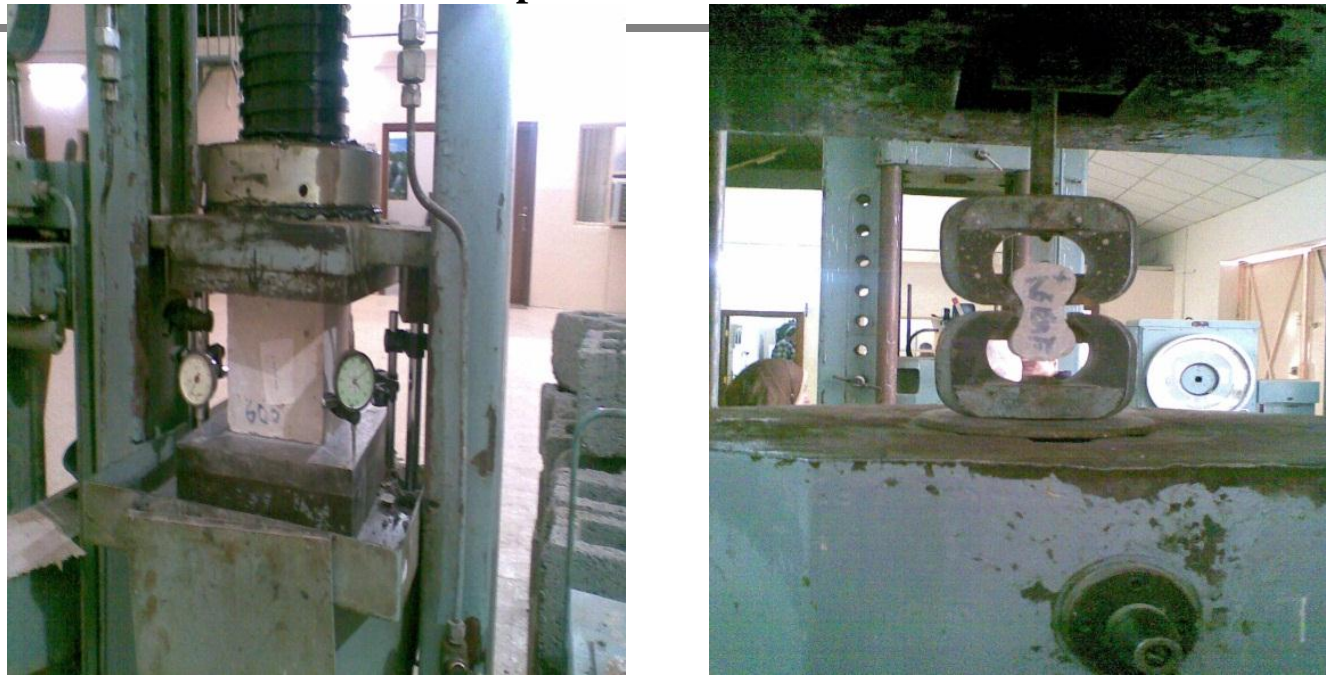

Fig. (1) Testing of specimens

\section{Results and Discussion:}

The stress-strain relations of glass fiber concrete are shown in Fig. 2. It can be seen that the fiber reinforced concrete bear highest stress for same amount of strain. The stresses increased by $(3.6,7.1,9.3) \%$ for the fibers content $(600,1000,1400) \mathrm{gm} / \mathrm{m}^{3}$ respectively

Fig.(3) Shows that the compressive strength of concrete cubic specimens $(150 * 150) \mathrm{mm}$ increased by $(3.6,7.1,9.3) \%$ for the fibers content $(600,1000,1400) \mathrm{gm} / \mathrm{m}^{3}$

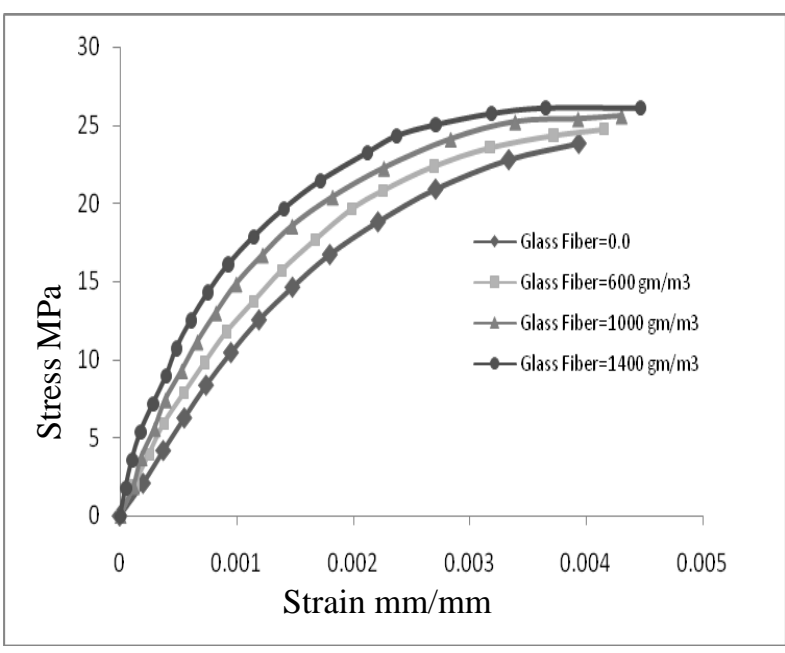

Fig.(2) Stress-strain curve for different glass fiber content

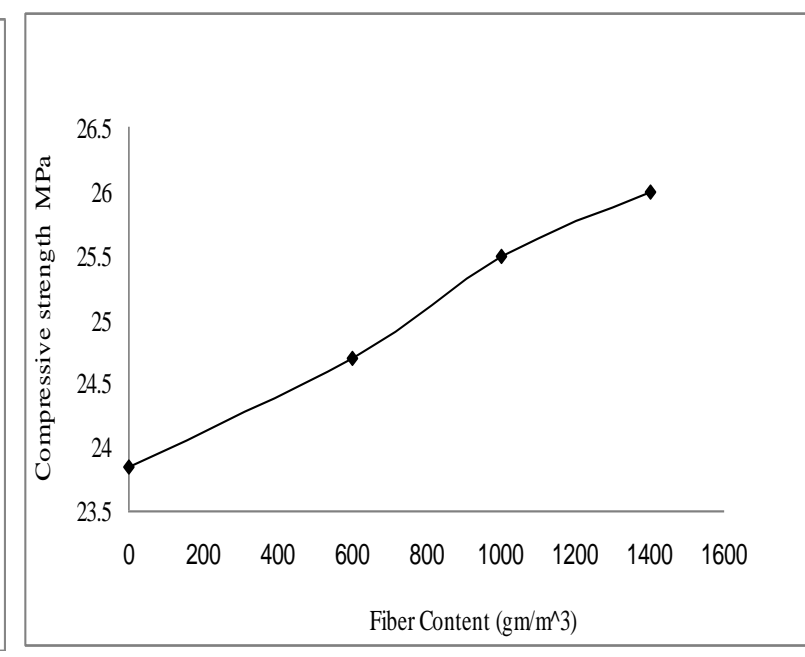

Fig. (3) Compressive strength at different fiber conten

While Fig (4) shows the compressive strength of mortar with different fiber content. It can be seen that the optimum compressive strength obtain with fibers contain of $(600) \mathrm{gm} / \mathrm{m}^{3}$ and decreased when the fibers contain increased up to $(1000,1400) \mathrm{gm} / \mathrm{m}^{3}$

A splitting tensile strength was tested for the cylinder specimens $(150 * 300) \mathrm{mm}$ and the result showed an increase of (1, 4.3 and 12.5) \% as shown in Fig. (5). and for the mortar brackets specimens were tested, fig. (6) Showed that the tensile strength for this specimens increased by $(5.4,7.7,17) \%$ for the fibers content of $(600,1000,1400) \mathrm{gm} /$ 


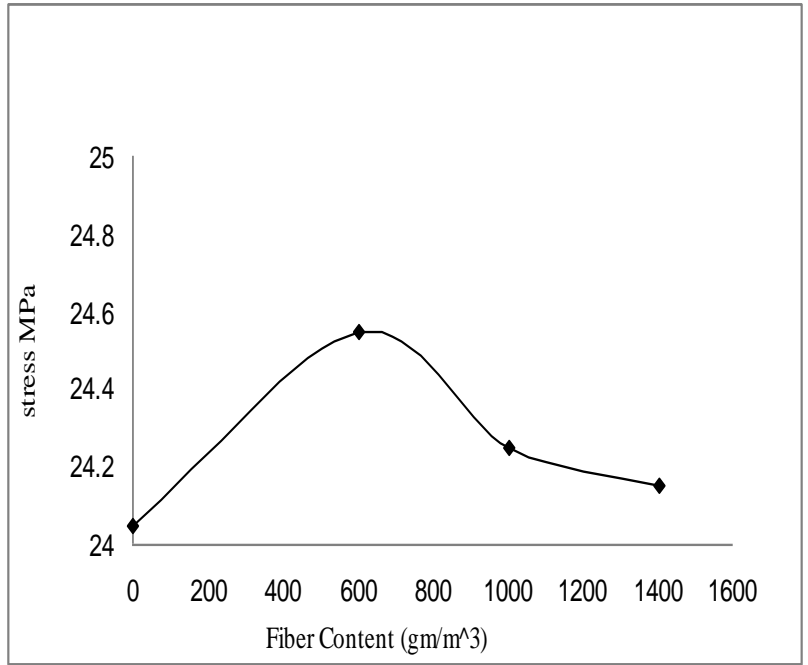

Fig.(4) Compressive strength for mortar at different fiber content

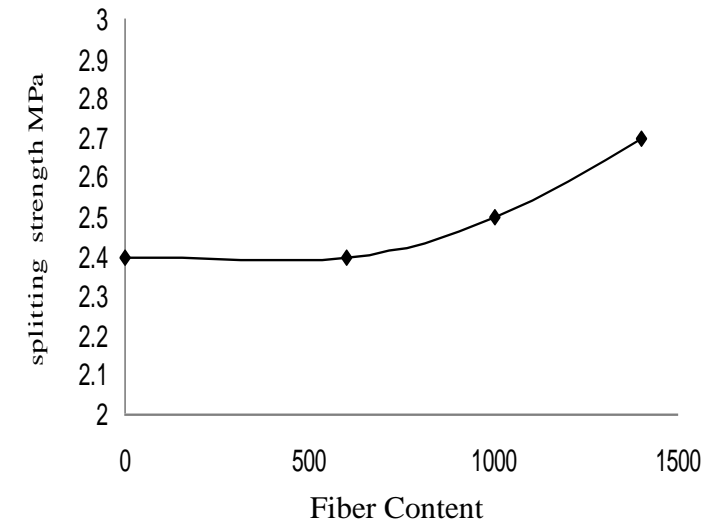

Fig. (5) Splitting Tensile Strength for concrete at different fiber content

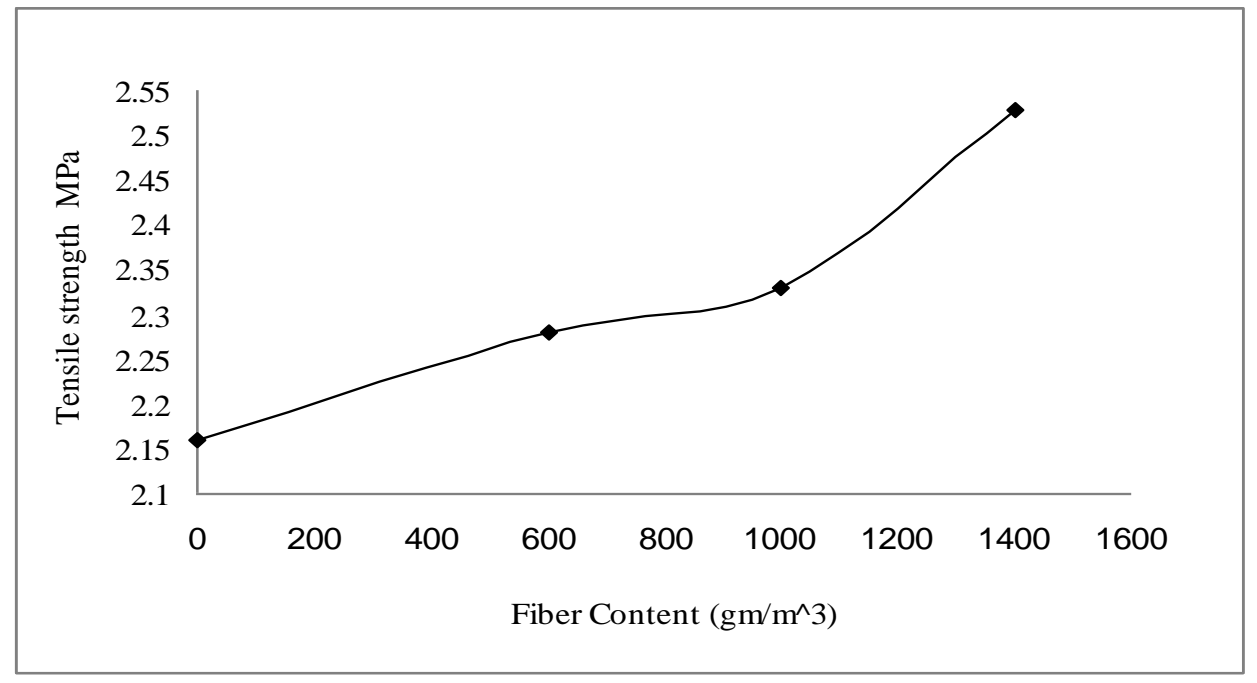

Summary of all the above result are shown in table (6) .

Table (6) shows the result above.

\begin{tabular}{|c|c|c|c|c|}
\hline \multirow{2}{*}{$\begin{array}{c}\text { fiber content } \\
\mathbf{g m} / \mathbf{m 3}\end{array}$} & \multicolumn{2}{|c|}{ Concrete } & \multicolumn{2}{c|}{ Mortar } \\
\cline { 2 - 5 } & Fc' $^{\mathbf{M P a})}$ & $\begin{array}{c}\text { Ft } \\
\mathbf{( M P a})\end{array}$ & $\mathbf{F c}^{\prime}$ (MPa) & $\begin{array}{c}\text { Ft } \\
\mathbf{M P a})\end{array}$ \\
\hline 0 & 23.85 & 2.4 & 24.05 & 2.16 \\
\hline 600 & 24.7 & 2.4 & 24.55 & 2.28 \\
\hline 1000 & 25.5 & 2.5 & 24.25 & 2.33 \\
\hline 1400 & 26.0 & 2.7 & 24.15 & 2.53 \\
\hline
\end{tabular}

The relation between $\mathbf{F} \mathbf{c}^{\prime}$ and $\mathbf{F t}$ for concrete and mortar can be obtained from the equations below:

1. for concrete:

$f_{c}^{\prime}=-33.33 * f_{t}^{2}+175.8 * f_{t}-205.7$. 
2. for mortar:

$\left.f_{c}^{\prime}=-9.14 * f_{t}^{2}+43.16 .8 * f_{t}-26.54\right)$

Elastic modulus, or modulus of elasticity, is the mathematical description of an object or substance's tendency to be deformed elastically (i.e., non-permanently) when force is applied to it.

The elastic modulus of an object is defined as the slop in the elastic deformation region [8] curve of its. Fig. (7) Show that the Modulus of elasticity of the glass fiber reinforced concrete increased by $84 \%$ as the fiber content increased from zero to $1400 \mathrm{gm} / \mathrm{m}^{3}$ while it increased about $10 \%$ when the fiber content increased from zero to $600 \mathrm{gm} / \mathrm{m}^{3}$, with the knowledge that the Modulus of elasticity is calculated at $40 \%$ of maximum stress,. According to ASTM C469-02 [9].

One of the principal challenges in structural engineering concerns the development of modern design concepts to better protect structures, with the occupants and contents, from the damaging effects of destructive environmental forces including those due to winds, waves and earthquakes. Passive energy dissipation devices, when incorporated into a structure, absorb or consume a portion of the input energy, thereby reducing energy dissipation demand on primary structural members and minimizing possible structural damage. [10].

Fig. (8) Show the result of Energy dissipated which is defined as (area under the load-deflection curve or stress-strain curve). The area under the load-deflection curve I usually referred to as the toughness obtained from a static test of a beam specimen up to a specified deformation (not to be confused with the fracture toughness). It can be seen that using the glass fiber in concrete enhancing the energy absorption of the concrete. [11].

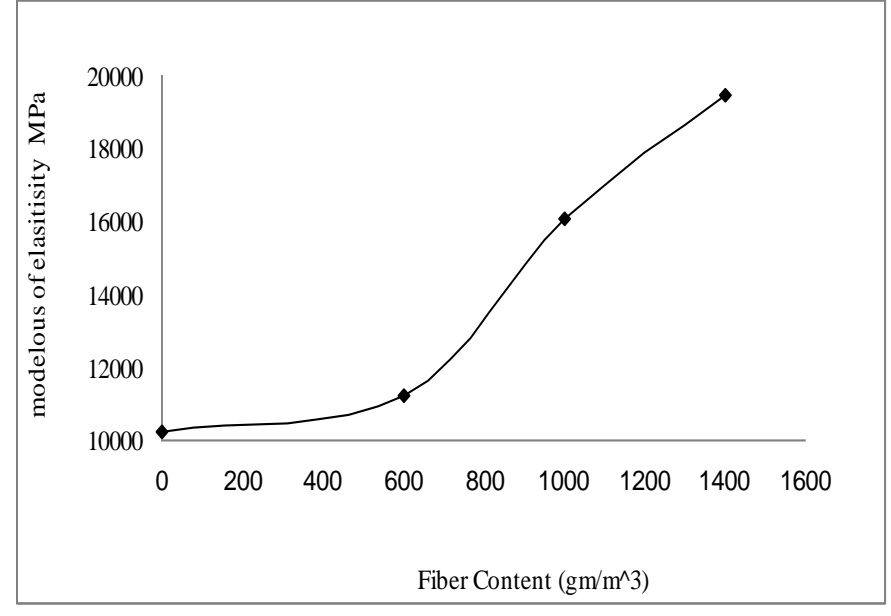

Fig. (7) Modules of elasticity for concrete at different fiber contents.

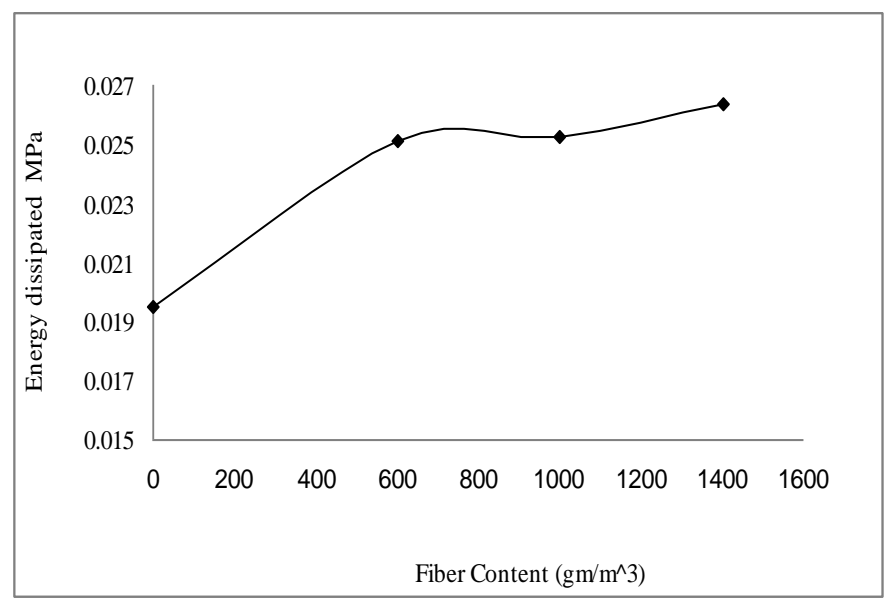

.Fig. (8) Energy dissipated for concrete at different fiber contents 


\section{CONCLUSIONS}

Using the glass fiber as reinforcement for concrete and mortar enhanced their mechanical properties as

1. The addition of glass fiber in concrete increases the compressive strength by $(3.6,7.1,9.3) \%$ for the fibers content $(600,1000,1400) \mathrm{gm} / \mathrm{m}^{3}$, and for the mortar increases by (2) $\%$ for fibers contain $(600) \mathrm{gm} / \mathrm{m}^{3}$ and increased $(0.8,0.4) \%$ for fibers content $(1000,1400) \mathrm{gm} / \mathrm{m}^{3}$ respectively.

2. The addition of glass fiber in concrete increases the splitting tensile strength by $(1,4.3,12.5) \%$ for the fibers content $(600,1000,1400) \mathrm{gm} / \mathrm{m}^{3}$, and the tensile strength of mortar increases by $(5.4,7.7,17) \%$ for the same fiber contend.

3. The modulus of elasticity of glass fiber reinforced concrete increased by $(9.7,56.6$, $84) \%$ for the fibers ratio $(600,1000$, and 1400$) \mathrm{gm} / \mathrm{m}^{3}$.

4. The energy discorporate of glass fiber reinforced concrete increased by $(29.1,29.7$, and 35.4$) \%$ for the fibers ratio $\left(600,1000\right.$, and 1400) $\mathrm{gm} / \mathrm{m}^{3}$.

5. the splitting tensile strength of GFRC ranged from $9 \%$ to $11 \%$ of its compressive strength, comparing with the author Choi and Yuan [3] which was 9\% to $13 \%$

\section{References:}

[1].B. Ilschner et al., 15 June, (2000). "Composite Materials", and Ullmann's Encyclopedia of Industrial Chemistry (Weinheim, Germany: Wiley-VCH Verlag GmbH \& Co. $\mathrm{KGaA}$ ).

[2].Junji Takagi, Some Properties of glass fiber reinforced concrete, fiber reinforced concrete, ACI SP-44, Detroit, Michigan, 1974, PP. 93-111 .

[3]. Yeol Choi, Robert L.Yuan, Experimental relationship between splitting tensile strength and compressive strength of GFRC and PFRC, Cement and Concrete Research 35, 2005, pp. 1587-1591.

[4]. P.S. Song, S. Hwang, B.S. Sheu, Strength properties of nylon-and polypropylene- Fiber -reinforced concretes, Cement and Concrete Research 35, 2005, pp. 1546-1550.

[5].IQS No: 5, 1984"Characteristics of OPC" Central Agency for standardization and quality control, Iraq, 1984.

[6]. ASTM C150 / C150M - 09 Standard Specification for Portland Cement.

[7].BS 882-1992, Aggregate from natural source for concrete " British standard in stitution ,1992.

[8].Askeland, Donald R.; Phulé, Pradeep P. (2006). The science and engineering of materials (5th ed.). Cengage Learning. p. 198. ISBN 978-0-53-455396-8.

[9].ASTM C469-02,"Static modulus of Elasticity and poisons Ratio of Concrete in Compression", American Society for Testing and Materials ,2002

[10]. T. T. Soong and G. F. Dargush, Passive Energy Dissipation Systems in Structural Engineering, Wiley, 368.

[11]. Thammasa Int. J. "Toughness valuation of Steel and Polypropylene Fiber Reinforced Concrete Beams under Bending", Sc. Tech. Vol. 9, No. 3, July-September, 2004.

The work was carried out at the college of Engineering. University of Mosul 